14 van Rijn RR, Lequin MH, Robben SG, et al. Is the Greulich and Pyle atlas still valid for Dutch Caucasian children today? Pediatr Radiol 2001;31:748-52.

15 Koc A, Karaoglanoglu M, Erdogan M, et al. Assessment of bone ages: is the Greulich-Pyle method sufficient for Turkish boys? Pediatr Int 2001;43:662-5.

16 Guimarey L, Moreno Morcillo A, Orazi V, et al. Validity of the use of a few hand-wrist bones for assessing bone age. J Pediatr Endocrinol Metab 2003; 16:541-4.

17 Lewis CP, Lavy CB, Harrison WJ. Delay in skeletal maturity in Malawian children. $J$ Bone Joint Surg Br 2002;84:732-4.

18 Zhen OY, Baolin L. Skeletal maturity of the hand and wrist in Chinese school children in Harbin assessed by the TW2 method. Ann Hum Biol 1986; 13:183-7.

19 Ye YY, Wang CX, Cao LZ. Skeletal maturity of the hand and wrist in Chinese children in Changsha assessed by TW2 method. Ann Hum Biol 1992; 19:427-30

20 Murata M. Population-specific reference values for bone age. Acta Paediatr Suppl 1997;423:113-14.
21 Malina RM. Skeletal maturation studied longitudinally over one year in American Whites and Negroes six though thirteen years of age. Hum Biol 1970;42:377-90.

22 Malina RM. A consideration of factors underlying the selection of methods in the assessment of skeletal maturity. Am J Phys Anthropol 1971;35:341-6.

23 Malina RM, Little BB. Comparison of TW1 and TW2 skeletal age differences in American black and white and in Mexican children 6-13 years of age. Ann Hum Biol 1981;8:543-8.

24 Loder RT, Estle DT, Morrison K, et al. Applicability of the Greulich and Pyle skeletal age standards to black and white children of today. Am J Dis Child 1993;147:1329-33.

25 Mora S, Boechat MI, Pietka E, et al. Skeletal age determinations in children of European and African descent: applicability of the Greulich and Pyle standards. Pediatr Res 2001;50:624-8.

26 Ontell FK, lvanovic $M$, Ablin DS, et al. Bone age in children of diverse ethnicity. AJR Am J Roentgenol 1996;167:1395-8.

\title{
EDITORIAL BOARD MEMBER
}

\section{Peter Brukner}

$P$ eter Brukner, OAM, MBBS, FACSP, FACSM, FASMF, is currently associate professor in sports medicine at the Centre for Health, Exercise and Sports Medicine at the University of Melbourne. Peter has been clinic director at the Olympic Park Sports Medicine Centre in Melbourne since 1987 and has served two terms as president of the Australian College of Sports Physicians, during which time he was instrumental in the establishment of a specialist level training programme in Australia for sports medicine physicians. He has published widely internationally, with a number of books, book chapters and original research articles. Peter is the co-author of Clinical sports medicine. He was an Australian team physician at the Atlanta Olympic Games and team manager of the Australian athletics team at the Sydney Olympics, as well as serving as team physician for professional football clubs, national athletics, swimming and men's hockey teams. He was recently awarded the medal of the Order of Australia (OAM) for services to sports medicine.

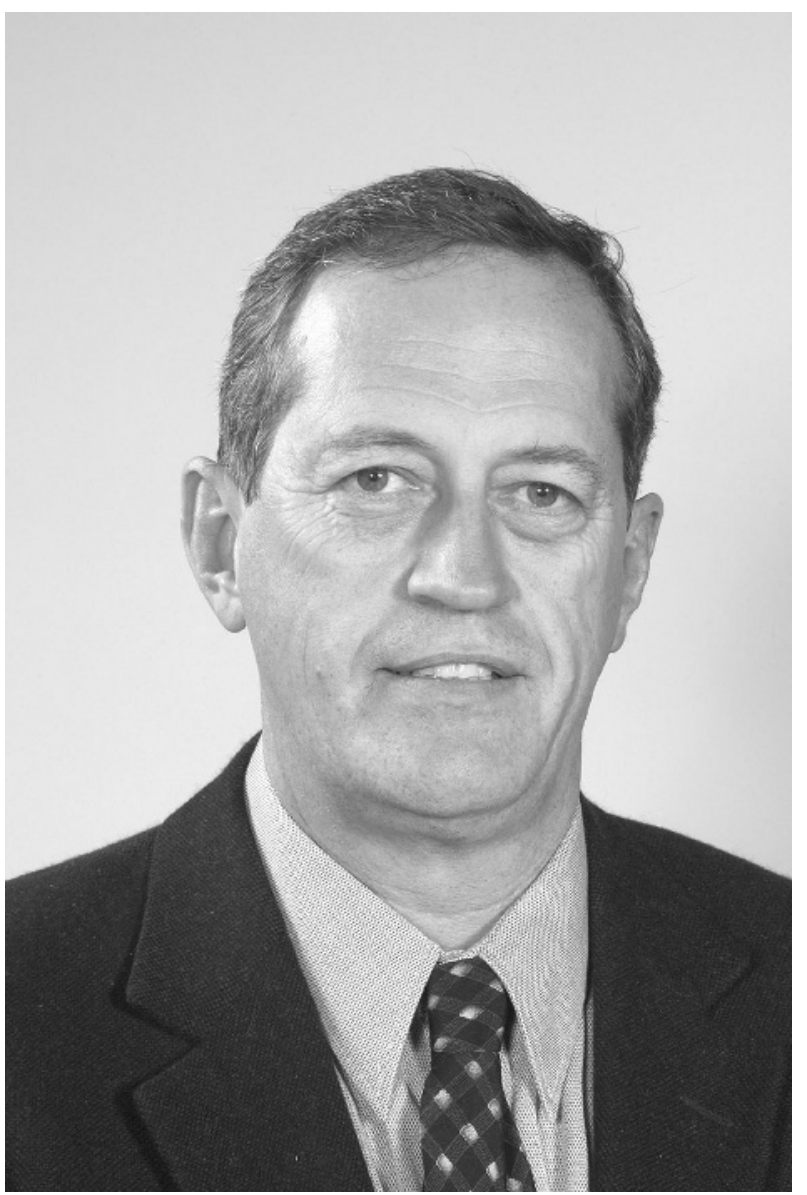

Figure 1 Peter Brukner. 